\title{
Synthesis, characterization and emission properties of quinolin-8-olato chelated ruthenium organometallics
}

\author{
BIKASH KUMAR PANDA \\ Department of Inorganic Chemistry, Indian Association for the Cultivation of Science, Kolkata 700032 , \\ India \\ e-mail: b_panda@hotmail.com
}

MS received 2 June 2004; revised 21 July 2004

\begin{abstract}
The reaction of $\mathrm{Ru}\left(\mathrm{RL}^{1}\right)\left(\mathrm{PPh}_{3}\right)_{2}(\mathrm{CO}) \mathrm{Cl}$, 1, with quinolin-8-ol (HQ) has afforded complexes of the type $\left[\mathrm{Ru}\left(\mathrm{RL}^{2}\right)\left(\mathrm{PPh}_{3}\right)_{2}(\mathrm{CO})(\mathrm{Q})\right]$, 3, in excellent yield $\left(\mathrm{RL}^{1}\right.$ is $\mathrm{C}_{6} \mathrm{H}_{2} \mathrm{O}-2-\mathrm{CHNHC}_{6} \mathrm{H}_{4} \mathrm{R}(p)-3-\mathrm{Me}-5$, $\mathrm{RL}^{2}$ is $\mathrm{C}_{6} \mathrm{H}_{2} \mathrm{OH}-2-\mathrm{CHNC}_{6} \mathrm{H}_{4} \mathrm{R}(p)-3-\mathrm{Me}-5$ and $\mathrm{R}$ is $\mathrm{Me}, \mathrm{OMe}, \mathrm{Cl}$ ). In this process, quinolin-8-olato (Q) undergoes five-membered chelation, the iminium-phenolato function tautomerizing to the imine-phenol function. In dichloromethane solution, 3 displays a quasireversible $3^{+} / 3$ couple near $0.50 \mathrm{~V}$ vs $\mathrm{SCE}\left(3^{+}\right.$is the ruthenium (III) analogue of $\mathbf{3}$ ). Coulometrically generated solutions of $\mathbf{3}^{+}$display a strong absorption near $395 \mathrm{~nm}$ associated with a shoulder near $475 \mathrm{~nm}$ and rhombic EPR spectra with $g$ values near $2 \cdot 55$, $2 \cdot 13,1.89$. Solutions of 3 absorb near $415 \mathrm{~nm}$ and emit near $510 \mathrm{~nm}$ at $298 \mathrm{~K}$ and $585 \mathrm{~nm}$ at $77 \mathrm{~K}$. The fluorescence is believed to originate from the ${ }^{3}$ MLCT state.
\end{abstract}

Keywords. Ruthenium organometallics; quinolin-8-olato chelation; emission properties; trivalent ruthenium.

\section{Introduction}

There is continuing interest in the chemistry of ruthenium, ${ }^{1-4}$ primarily due to the fascinating electrontransfer properties exhibited by complexes of this metal. Variation of the coordination environment around ruthenium plays a key role in modulating the redox properties of its complexes. In particular, the chem.istry of orthometallated ruthenium compounds is of current interest in the context of synthesis, ${ }^{5-7}$ reactivity ${ }^{6,8-12}$ and photophysical properties. ${ }^{13,14}$ It was demonstrated that the decarbonylative metallation of 4-methyl-2,6-diformyl phenol by $\mathrm{Ru}\left(\mathrm{PPh}_{3}\right)_{3} \mathrm{Cl}_{2}$ in the presence of primary aromatic amines $\left(\mathrm{RC}_{6} \mathrm{H}_{4} \mathrm{NH}_{2}\right)$ is known to furnish four-membered ruthenium organometallics of type $\mathrm{Ru}\left(\mathrm{RL}^{1}\right)\left(\mathrm{PPh}_{3}\right)_{2}$

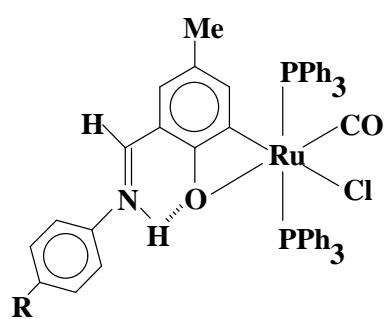

1

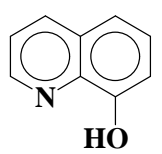

2
$(\mathrm{CO}) \mathrm{Cl}(\mathbf{1})$ juxtaposed to a hydrogen-bonded iminium-phenolato function. ${ }^{15-17} \mathrm{We}$ are scrutinizing the reactivity of these compounds. Thus alkynes and isonitriles have been found to promote metallacyclic expansion, ${ }^{8,9,11,18}$ bidentate monoanionic $\sigma$-donor reagents such as acetate, nitrate, nitrite, xanthate and pyridine-2-thiolate undergo four-memberad chelation, ${ }^{19-22}$ and electroneutral $\alpha$-diimine ligands such as bipyridine, phenanthroline furnish five-membered ruthenium organometallics. ${ }^{23}$

The richness of this reaction chemistry has now prompted us to explore the reactivity of $\mathbf{1}$ towards quinolin-8-ol, 2, (HQ, H stands for the dissociable phenolic hydrogen) which is suited for five-membered $\mathrm{N}$, O-chelation. A facile reaction is indeed observed affording five-membered ruthenium organometallics via displacement of $\mathrm{Ru}-\mathrm{O}$ and $\mathrm{Ru}-\mathrm{Cl}$ bonds. Changes in the coordination mode and tautomeric state of the Schiff base ligand accompany the synthetic reaction. It may be noted here that the chemistry of ruthenium quinolin-8-olates appears to have received relatively less attention, ${ }^{24-28}$ but organoruthenium compounds incorporating quinolin-8-olates are unprecedented. A point of special interest is that such species are potentially luminescent in the visible region. 


\section{Experimental}

\subsection{Materials}

The compounds $\mathrm{Ru}\left(\mathrm{PPh}_{3}\right)_{2} \mathrm{Cl}_{2}{ }^{29}$ and $\mathrm{Ru}\left(\mathrm{RL}^{1}\right)\left(\mathrm{PPh}_{3}\right)_{2}$ (CO) $\mathrm{Cl}^{15}$ were prepared by reported methods. Quinolin-8-ol was obtained from Merck. The purification of dichloromethane and the preparation of tetraethyl ammonium perchlorate (TEAP) for electrochemical work were done as described in previous work. ${ }^{30}$ All other chemicals and solvents were of analytical grade and were used as received.

\subsection{Physical measurements}

Electronic, IR and fluorescence spectra were recorded with a Shimadzu UV-1601 PC spectrophotometer, Nicolet Magna IR series II spectrometer and Perkin-Elmer model LS 55 luminescence spectrometer respectively. ${ }^{1} \mathrm{H}$ NMR spectra were obtained using a Bruker $300 \mathrm{MHz}$ FT NMR spectrometer. The numbering scheme used for the ${ }^{1} \mathrm{H}$ NMR is the same as shown in drawing 3. Microanalyses $(\mathrm{C}, \mathrm{H}$, $\mathrm{N})$ were done by using a Perkin-Elmer $240 \mathrm{C}$ elemental analyzer. The magnetic behaviour of the complexes was examined by a PAR 155 vibrating sample magnetometer. EPR spectra were recorded on a Varian E-109C X-band spectrometer fitted with a quartz dewar. Solution electrical conductivity was measured in acetone with a Phillips PR 9500 bridge using a platinized electrode (cell constant of 1.05). Electrochemical measurements were performed in a nitrogen atmosphere in dichloromethane solution using a CHI model 620A electrochemical analyzer. The supporting electrolyte was tetraethyl ammonium perchlorate and potentials are referenced to the saturated calomel electrode.

\subsection{Synthesis of the complexes $\left[R u\left(R L^{2}\right)\left(P P h_{3}\right)_{2}\right.$ $(C O)(Q)](3)$}

$\left[\mathrm{Ru}\left(\mathrm{RL}^{2}\right)\left(\mathrm{PPh}_{3}\right)_{2}(\mathrm{CO})(\mathrm{Q})\right](3)$ complexes were synthesized in excellent yield $(\sim 85 \%)$ by reacting $\mathrm{Ru}\left(\mathrm{RL}^{1}\right)\left(\mathrm{PPh}_{3}\right)_{2}(\mathrm{CO}) \mathrm{Cl}(\mathbf{1})$ in $\mathrm{MeOH}-\mathrm{CH}_{2} \mathrm{Cl}_{2}(2: 1)$ at room temperature with excess HQ. Details of a representative case are given below. The other compounds are prepared in an analogous manner.

2.3a $\quad\left[R u\left(\mathrm{MeL}^{2}\right)\left(\mathrm{PPh}_{3}\right)_{2}(\mathrm{CO})(\mathrm{Q})\right] \quad 3 \quad(\mathrm{Me}):$ To a vigorously stirred violet solution of $\mathrm{Ru}\left(\mathrm{MeL}^{1}\right)$ $\left(\mathrm{PPh}_{3}\right)_{2}(\mathrm{CO}) \mathrm{Cl}(100 \mathrm{mg}, 0.109 \mathrm{mmol})$ in a mixture of $40 \mathrm{ml}$ methanol and $20 \mathrm{ml}$ dichloromethane was added $48 \mathrm{mg}(0.331 \mathrm{mmol})$ of HQ. The mixture was stirred for $4 \mathrm{~h}$ when the colour of the solution changed from violet to yellow. The solvent was then removed under reduced pressure and the yellow solid thus obtained was washed with a little amount of methanol (removal of excess HQ). The residue was recrystallized from dichloromethane-hexane $(1: 3)$ mixture followed by drying in vacuo. Yield: $96 \mathrm{mg}$ (86\%).

Analysis: Calc. for $\mathrm{C}_{61} \mathrm{H}_{50} \mathrm{~N}_{2} \mathrm{O}_{3} \mathrm{P}_{2} \mathrm{Ru}: \mathrm{C}, 69 \cdot 13 ; \mathrm{H}$, $4.54 ; \mathrm{N}, 2.69 \%$. Found C, 69.08; H, 4.50; N, 2.63\%.

${ }^{1} \mathrm{H}$ NMR (300 MHz, $\mathrm{CDCl}_{3}$, ppm, $298 \mathrm{~K}$ ): 12.93 $\left(s, 1 \mathrm{H}, \mathrm{O}-\mathrm{H}\right.$, disappeared upon shaking with $\mathrm{D}_{2} \mathrm{O}$ ), $8.05(s, 1 \mathrm{H}, \mathrm{H} 7), 6.23(s, 1 \mathrm{H}, \mathrm{H} 3), 1.70(s, 3 \mathrm{H}, 4-$ $\mathrm{Me}), 2.38(s, 3 \mathrm{H}, 13-\mathrm{Me}), 8.24\left(d, J_{H H}=6.3 \mathrm{~Hz}, 1 \mathrm{H}\right.$, H16), $7.43\left(d, J_{H H}=8.4 \mathrm{~Hz}, 1 \mathrm{H}, \mathrm{H} 18\right), 6.36(d$, $\left.J_{H H}=7.8 \mathrm{~Hz}, 1 \mathrm{H}, \mathrm{H} 19\right), 6.71\left(d, J_{H H}=8.1 \mathrm{~Hz}, 1 \mathrm{H}\right.$, $\mathrm{H} 21), 6.58-6.63(m, 2 \mathrm{H}, \mathrm{H} 17, \mathrm{H} 20) .6 \cdot 90-7.23$ ( $m$, $\left.35 \mathrm{H}, 2 \mathrm{PPh}_{3}, \mathrm{H} 5, \mathrm{H} 11, \mathrm{H} 12, \mathrm{H} 14, \mathrm{H} 15\right)$.

IR $\left(\mathrm{KBr}, \mathrm{cm}^{-1}\right)$ : $1899\left(\mathrm{v}_{\mathrm{CO}}\right), 1590\left(\mathrm{v}_{\mathrm{C}=\mathrm{N}}\right)$.

2.3b $\quad\left[\mathrm{Ru}\left(\mathrm{MeOL}^{2}\right)\left(\mathrm{PPh}_{3}\right)_{2}(\mathrm{CO})(\mathrm{Q})\right] \quad 3 \quad(\mathrm{OMe}): \mathrm{Ru}$ $\left(\mathrm{MeOL}^{1}\right)\left(\mathrm{PPh}_{3}\right)_{2}(\mathrm{CO}) \mathrm{Cl}(100 \mathrm{mg}, 0.107 \mathrm{mmol})$ and HQ $(47 \mathrm{mg}, 0.324 \mathrm{mmol})$ were employed. Yield: $93 \mathrm{mg}(83 \%)$.

Analysis: Calc. for $\mathrm{C}_{61} \mathrm{H}_{50} \mathrm{~N}_{2} \mathrm{O}_{4} \mathrm{P}_{2} \mathrm{Ru}: \mathrm{C}, 71.68 ; \mathrm{H}$, $4.93 ; \mathrm{N}, 2.74 \%$. Found C, 71.63; H, 4.96; N, $2.77 \%$.

${ }^{1} \mathrm{H}$ NMR (300 MHz, $\mathrm{CDCl}_{3}$, ppm, $298 \mathrm{~K}$ ): 12.95 $\left(s, 1 \mathrm{H}, \mathrm{O}-\mathrm{H}\right.$, disappeared upon shaking with $\mathrm{D}_{2} \mathrm{O}$ ), $8.04(s, 1 \mathrm{H}, \mathrm{H} 7), 6.22(s, 1 \mathrm{H}, \mathrm{H} 3), 1.70(s, 3 \mathrm{H}, 4-$ $\mathrm{Me}), 3.85(s, 3 \mathrm{H}, 13-\mathrm{OMe}) .8 .23\left(d, J_{H H}=6.5 \mathrm{~Hz}\right.$, $1 \mathrm{H}, \mathrm{H} 16), 7.44\left(d, J_{H H}=8.5 \mathrm{~Hz}, 1 \mathrm{H}, \mathrm{H} 18\right), 6.36(d$, $\left.J_{H H}=7.5 \mathrm{~Hz}, 1 \mathrm{H}, \mathrm{H} 19\right), 6.71\left(d, J_{H H}=7.8 \mathrm{~Hz}, 1 \mathrm{H}\right.$, $\mathrm{H} 21), 6.58-6.62(m, 2 \mathrm{H}, \mathrm{H} 17, \mathrm{H} 20), 6.92-7.25(m$, $\left.35 \mathrm{H}, 2 \mathrm{PPh}_{3}, \mathrm{H} 5, \mathrm{H} 11, \mathrm{H} 12, \mathrm{H} 14, \mathrm{H} 15\right)$.

IR $\left(\mathrm{KBr}, \mathrm{cm}^{-1}\right)$ : $1904\left(\mathrm{v}_{\mathrm{CO}}\right), 1609\left(\mathrm{v}_{\mathrm{C}=\mathrm{N}}\right)$.

2.3c $\quad\left[\mathrm{Ru}\left(\mathrm{ClL}^{2}\right)\left(\mathrm{PPh}_{3}\right)_{2}(\mathrm{CO})(\mathrm{Q})\right] \mathbf{3}(\mathrm{Cl}): \mathrm{Ru}\left(\mathrm{ClL}^{1}\right)$ $\left(\mathrm{PPh}_{3}\right)_{2}(\mathrm{CO}) \mathrm{Cl} \quad(100 \mathrm{mg}, \quad 0.107 \mathrm{mmol})$ and HQ (47 mg, 0.324 mmol) were used. Yield: $90 \mathrm{mg}(81 \%)$.

Analysis: Calc. for $\mathrm{C}_{60} \mathrm{H}_{47} \mathrm{~N}_{2} \mathrm{O}_{3} \mathrm{P}_{2} \mathrm{Ru}: \mathrm{C}, 70.58 ; \mathrm{H}$, $4.85 ; \mathrm{N}, 2.70 \%$. Found C, 70.52; H, 4.81; N, $2.73 \%$.

${ }^{1} \mathrm{H}$ NMR $\left(300 \mathrm{MHz}, \mathrm{CDCl}_{3}, \mathrm{ppm}, 298 \mathrm{~K}\right): 12.69$ $\left(s, 1 \mathrm{H}, \mathrm{O}-\mathrm{H}\right.$, disappeared upon shaking with $\left.\mathrm{D}_{2} \mathrm{O}\right)$, $8.04(s, 1 \mathrm{H}, \mathrm{H} 7), 6.25(s, 1 \mathrm{H}, \mathrm{H} 3), 1.72(s, 3 \mathrm{H}, 4-$ Me). $8.25\left(d, J_{H H}=6.1 \mathrm{~Hz}, 1 \mathrm{H}, \mathrm{H} 16\right), 7.47(d$, $\left.J_{H H}=8.2 \mathrm{~Hz}, 1 \mathrm{H}, \mathrm{H} 18\right), 6.38\left(d, J_{H H}=7.2 \mathrm{~Hz}, 1 \mathrm{H}\right.$, $\mathrm{H} 19), 6.73\left(d, J_{H H}=7.5 \mathrm{~Hz}, 1 \mathrm{H}, \mathrm{H} 21\right), 6.59-6.64$ $(m, 2 \mathrm{H}, \mathrm{H} 17, \mathrm{H} 20), 6 \cdot 88-7 \cdot 27\left(m, 35 \mathrm{H}, 2 \mathrm{PPh}_{3}, \mathrm{H} 5\right.$, H11, H12, H14, H15).

IR $\left(\mathrm{KBr}, \mathrm{cm}^{-1}\right): 1902\left(\mathrm{v}_{\mathrm{CO}}\right), 1602\left(\mathrm{v}_{\mathrm{C}=\mathrm{N}}\right)$. 


\section{Results and discussion}

\subsection{Chelation with quinolin-8-olato}

In methanol-dichloromethane solution, $\mathrm{Ru}\left(\mathrm{RL}^{1}\right)$ $\left(\mathrm{PPh}_{3}\right)_{2}(\mathrm{CO}) \mathrm{Cl}$ (1) reacts smoothly with three-fold excess of HQ upon stirring at room temperature, according to,

$$
\mathbf{1}+\mathrm{HQ} \rightarrow \mathbf{3}+\mathrm{HCl}
$$

The colour of the solution changes from violet to yellow, from which $\left[\mathrm{Ru}\left(\mathrm{RL}^{2}\right)\left(\mathrm{PPh}_{3}\right)_{2}(\mathrm{CO})(\mathrm{Q})\right](3)$ is obtained in excellent yield. The $\mathrm{R}$ groups utilized in the present work are $\mathrm{Me}, \mathrm{OMe}$ and $\mathrm{Cl}$. Specific compounds are identified by putting $\mathrm{R}$ in parentheses: thus $3(\mathrm{Me})$ stands for $\left[\mathrm{Ru}\left(\mathrm{MeL}^{2}\right)\left(\mathrm{PPh}_{3}\right)_{2}(\mathrm{CO})\right.$ (Q)]. The complex 3 has been isolated in pure form in $>85 \%$ yield. An isomer (because quinol-8-ol is unsymmetrical) of $\mathbf{3}$ is possible in principle but it has never been observed. Careful examination of ${ }^{1} \mathrm{H}$ NMR spectra of crude sample (before recrystallization) did not reveal the presence of any extra signals apart from those characterizing $\mathbf{3}$. We assign structure 3 to it in analogy with the stereochemistry of other $\mathrm{Ru}^{\mathrm{II}}$ (quinolin-8-olato) complexes ${ }^{26,28}$ and also by comparing with pyridine-2-thiolate chelated ruthenium organometallics. ${ }^{22}$

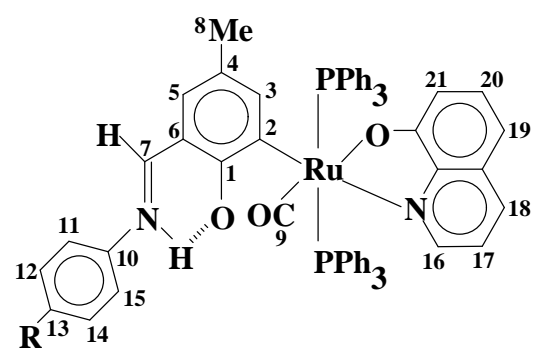

3

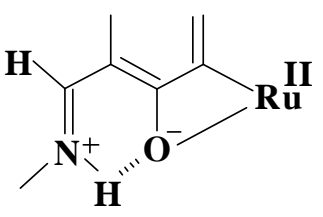

4<smiles>[R10]C(=C)C1=C(C)C=[Y](C)N[Y]1C</smiles>

5
The conversions $\mathbf{1} \rightarrow \mathbf{3}$ is attended with a prototropic shift within the salicyaldimine function. In $\mathbf{1}$ the metal is coordinated to phenolato oxygen and the Schiff base function occurs in the zwitterionic iminium-phenolato tautomeric form 4. Chelation of quinolin-8-olato is attended with the cleavage of the $\mathrm{Ru}-\mathrm{O}$ bond and the Schiff base function becomes an imine-phenol 5. This is fully consistent with the spectroscopic data.

Thus the $\mathrm{C}=\mathrm{N}$ stretching frequency in $\mathbf{3}$ is significantly lower $\left(\sim 1600 \mathrm{~cm}^{-1}\right)$ than that in $\mathbf{1}\left(\sim 1620 \mathrm{~cm}^{-1}\right)$ as expected. ${ }^{31}$ Also the aldimine $\mathrm{CH}$ signal in ${ }^{1} \mathrm{H}$ NMR in 3 (figure 1) occurs at lower field viz. $8.0 \mathrm{ppm}$ as compared to $\sim 7.5 \mathrm{ppm}$ in $1 .{ }^{15}$ The $\mathrm{O}-\mathrm{H}$ resonance in $\mathbf{3}$ is a relatively sharp signal near $13 \mathrm{ppm}$ having half-height width of $\sim 30 \mathrm{~Hz}$. In contrast, the iminium $\mathrm{N}-\mathrm{H}$ resonance in $\mathbf{1}$ is broad (width, $\sim 150 \mathrm{~Hz}$ ) evidently due to the quadrupole moment of the nitrogen atom. ${ }^{15}$ The prototropic transformation between $\mathbf{1}$ and $\mathbf{3}$ has certain similarities with the imine-iminium tautomerization in rhodopsins. $^{31}$

A plausible mechanism ${ }^{19}$ for the displacement of chloride in $\mathbf{1}$ consists of cis attack by $Q^{-}$is shown in 6. The anchored ligand displaces the phenolato oxygen and halide atoms achieving $Q^{-}$chelation with concomitant prototropic shift and conformational reorganization as in $\mathbf{7}$.
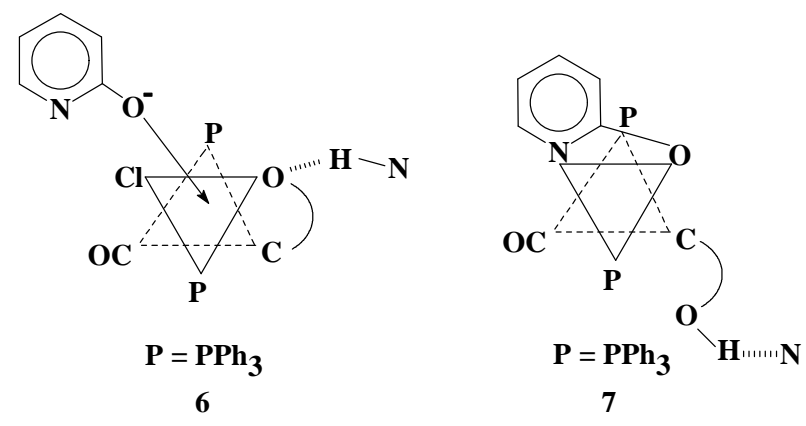

\subsection{Characterization}

Organometallics of type $\mathbf{3}$ are non-electrolytic in solution and are diamagnetic, consistent with a metal oxidation state of +2 . The $\mathrm{C} \equiv \mathrm{O}$ stretch is seen as a sharp band near $1900 \mathrm{~cm}^{-1}$.

In ${ }^{1} \mathrm{H}$ NMR (figure 1) the $3-\mathrm{H}$ proton of the metallated ring occur as sharp singlets near $6.2 \mathrm{ppm}$, while the $\mathrm{C}(4)-\mathrm{Me}$ protons resonate near $1.7 \mathrm{ppm}$. These protons are subject to shielding by phosphine phenyl rings. ${ }^{15,19,32}$ The $\mathrm{PPh}_{3}$, Schiff base $\left(\mathrm{C}_{6} \mathrm{H}_{4} \mathrm{R}\right)$ aromatic protons form a complex multiplet in the region $6 \cdot 80-7 \cdot 30 \mathrm{ppm}$ and the quinolin-8-olate aromatic protons appear in the $6 \cdot 20-8.30 \mathrm{ppm}$ region. Detailed assignments of the ligand protons are given 


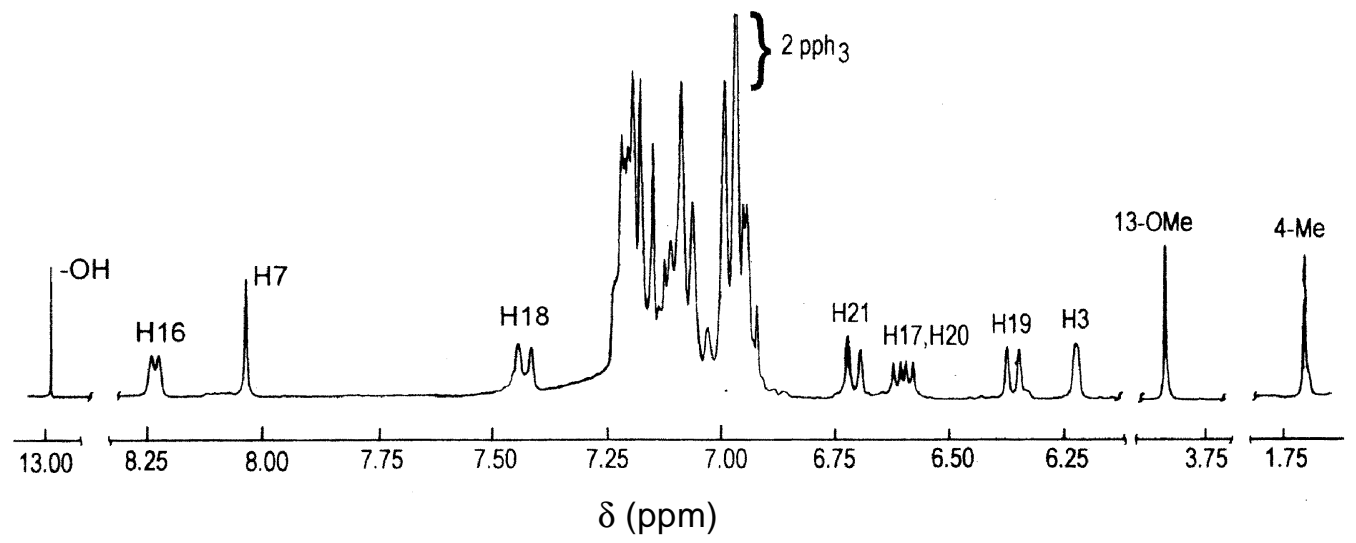

Figure 1. ${ }^{1} \mathrm{H} \mathrm{NMR}$ spectrum of $3(\mathrm{OMe})$ in $\mathrm{CDCl}_{3}$ solution.

Table 1. Spectral and electrochemical data of $\mathbf{3}$.

\begin{tabular}{|c|c|c|c|c|c|}
\hline \multirow[b]{2}{*}{ Complexes } & \multirow{2}{*}{$\begin{array}{c}\text { UV-Vis data }{ }^{\mathrm{a}} \\
\lambda_{\max }, \operatorname{nm}\left(\varepsilon^{\mathrm{b}}, \mathrm{M}^{-1} \mathrm{~cm}^{-1}\right)\end{array}$} & \multicolumn{2}{|c|}{$\begin{array}{l}\text { Emission data } \\
\lambda_{\max }, \mathrm{nm}\left(\phi_{r}\right)^{\mathrm{a}, \mathrm{c}}\end{array}$} & \multicolumn{2}{|c|}{ Electrochemical data } \\
\hline & & $298 \mathrm{~K}$ & $77 \mathrm{~K}$ & $E_{1 / 2}, V\left(\Delta E_{p}, \mathrm{mV}\right)^{\mathrm{d}}$ & $n^{\mathrm{e}}$ \\
\hline $3(\mathrm{Me})$ & 338 (17995) 410 (9720) & $507\left(2.01 \times 10^{-3}\right)$ & 586 & $0.52(184)$ & 1.09 \\
\hline $3(\mathrm{OMe})$ & $345(21715) 420(9800)$ & $506\left(1.74 \times 10^{-3}\right)$ & 584 & $0.48(102)$ & 1.02 \\
\hline $3(\mathrm{Cl})$ & 342 (16085) 415 (9447) & $513\left(1.30 \times 10^{-3}\right)$ & 587 & $0 \cdot 58(166)$ & $0 \cdot 96$ \\
\hline
\end{tabular}

a Solvent: dichloromethane; ${ }^{\mathrm{b}}$ molar absorption coefficient; ${ }^{\mathrm{c}}$ excitation at the higher wavelength absorption peak; ${ }^{\mathrm{d}}$ solvent: dichloromethane; $\Delta E_{p}$ is peak-to-peak separation; ${ }^{\mathrm{e}} n=Q / Q^{\prime}$ where $Q$ is the observed Coulomb count and $Q^{\prime}$ is the calculated Coulomb count for one-electron transfer

in the experimental section. In the previous section the chemical shifts of the imine-phenol protons were considered. The redox and photophysical properties of the complexes are examined in later sections.

\subsection{Electrochemistry: Trivalent ruthenium}

In dichloromethane solution $\mathbf{3}$ displays a quasireversible one-electron cyclic voltammetric response near $0.50 \mathrm{~V}$ (peak-to-peak separation is $\sim 100 \mathrm{mV}$ ) vs SCE corresponding to the couple

$$
\mathbf{3}^{+}+e \rightarrow \mathbf{3},
$$

where $3^{+}$represents the ruthenium(III) analogue of 3. A representative cyclic voltammogram is shown in figure 2. As $R$ is varied, the $E_{1 / 2}$ values increase in the Hammett order ${ }^{33} \mathrm{OMe}<\mathrm{Me}<\mathrm{Cl}$, see table 1 . The reduction potentials are systematically lower than those of the type 1 precursors ${ }^{15}$ by $\sim 200 \mathrm{mV}$, indicating better stabilization of the trivalent state in $\mathbf{3}$ compared with that in $\mathbf{1}$. The one-electron nature of the couple is consistent with the current height data compared to those of the one-electron standard $\left[\mathrm{Ru}(\mathrm{bpy})_{3}\right]^{2+}$. The exhaustive coulometric oxidation at $0.8 \mathrm{~V}$ affords a Coulomb count corresponding to one-electron transfer (table 1).

Trivalent organometallics $\mathbf{3}^{+}$, generated coulometrically, have been examined in solution. Their cyclic voltammograms (initial scan cathodic) are virtually superimposible on those of $\mathbf{3}$ (initial scan anodic), showing that $\mathbf{3}^{+}$retains the gross structure of $\mathbf{3}$. Orange-red solutions of $\mathbf{3}^{+}$are characterized by an intense band near $395 \mathrm{~nm}$ associated with a shoulder near $475 \mathrm{~nm}$ (table 2). The solutions are EPR-active when frozen into the glassy state (dichloromethanetoluene, $77 \mathrm{~K}$ ) giving rise to well-resolved rhombic spectra consistent with the low-spin $4 d^{5}$ configuration in a nonaxial geometry. ${ }^{24,34} \mathrm{~A}$ representative spectrum is shown in figure 3 and the $g$ values are listed in table 2.

\subsection{Photophysical properties}

In dichloromethane solution complexes of type $\mathbf{3}$ display two allowed absorption bands in the regions 
Table 2. Electronic and EPR spectral data of $\mathbf{3}^{+}$.

\begin{tabular}{|c|c|c|c|c|}
\hline \multirow[b]{2}{*}{ Complexes } & \multirow{2}{*}{$\begin{array}{c}\text { UV-Vis data }{ }^{\mathrm{a}} \\
\lambda_{\max }, \mathrm{nm}\left(\varepsilon^{\mathrm{b}}, \mathrm{M}^{-1} \mathrm{~cm}^{-1}\right)\end{array}$} & \multicolumn{3}{|c|}{ EPR $g$ values ${ }^{\mathrm{c}}$} \\
\hline & & $g_{1}$ & $g_{2}$ & $g_{3}$ \\
\hline $3(\mathrm{Me})^{+}$ & 330 (28850), 394(12903), 475 (3072) & $2 \cdot 529$ & $2 \cdot 124$ & $1 \cdot 895$ \\
\hline $3(\mathrm{OMe})^{+}$ & 338 (24090), 390 (12764), 477 (2542) & $2 \cdot 544$ & $2 \cdot 131$ & $1 \cdot 881$ \\
\hline $3(\mathrm{Cl})^{+}$ & 327 (22721), 397(10071), 472 (2007) & $2 \cdot 578$ & $2 \cdot 158$ & 1.896 \\
\hline
\end{tabular}

${ }^{\mathrm{a}}$ Solvent: dichloromethane; ${ }^{\mathrm{b}}$ molar absorption coefficient; ${ }^{\mathrm{c}}$ in $1: 1$ dichloromethane/toluene frozen glass $(77 \mathrm{~K})$

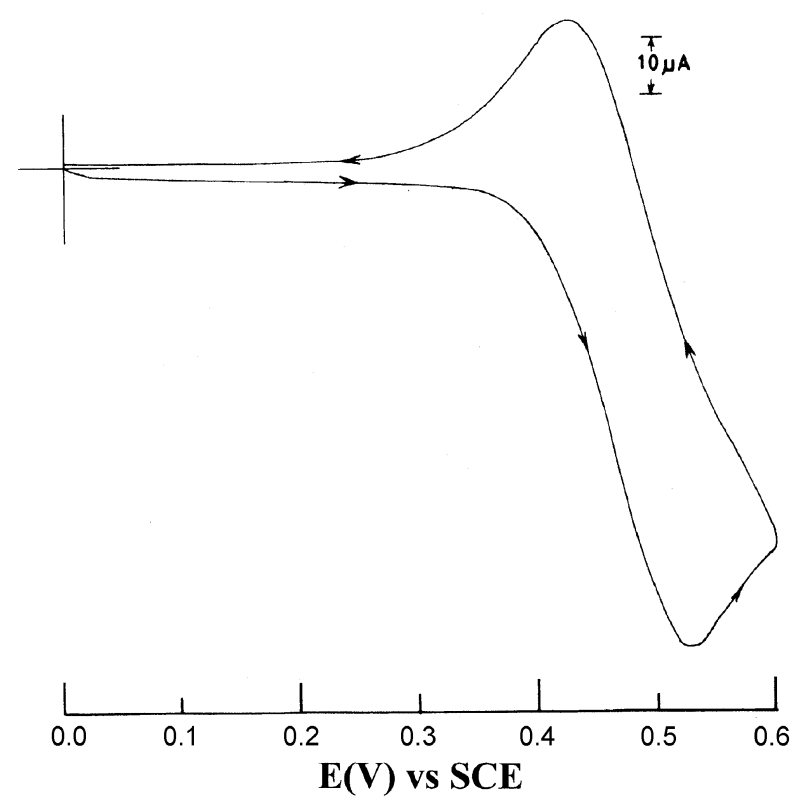

Figure 2. Cyclic voltammogram of $3(\mathrm{OMe})$ in dichloromethane solution.

$330-350$ and $400-420 \mathrm{~nm}$. The latter band is weaker in intensity and is believed to have significant $d \pi(\mathrm{Ru})-\pi^{*}(\mathrm{Q})$ MLCT character. Selected UV-Vis spectral data are given in table 1 . The solutions are fluorescent at room temperature, and also at low temperature $(77 \mathrm{~K})$. The peaks lying in the region $505-515$ and $580-590 \mathrm{~nm}$ at $298 \mathrm{~K}$ and $77 \mathrm{~K}$ respectively (figure 4, table 1) makes $\mathbf{3}$ fluorescent in the visible region. Low-temperature emission spectra are red-shifted from room temperature ones. The complexes are weak emitters, as noted from their quantum yield $\left(\phi_{r}\right)$ values which are one order of magnitude lower than that of the $\left[\mathrm{Ru}(\mathrm{bpy})_{3}\right]^{2+}$ standard $^{35}$ (table 1).

Quantum yields are calculated using equation (3) as described previously ${ }^{35}$ where $\phi_{\text {std }}$ is 0.042 at $298 \mathrm{~K}, A$ is the solution absorbance at the excitation wave length, $I$ is the relative emission intensity, $\eta$ are the refractive index values of the solvent for the
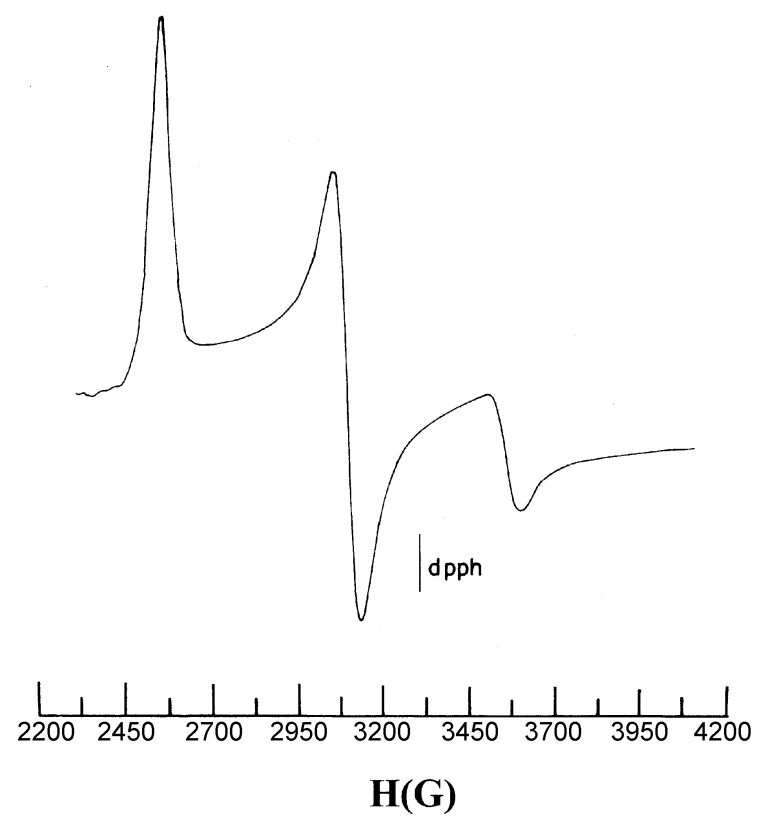

Figure 3. X-band EPR spectrum of electrogenerated 3 $(\mathrm{Cl})^{+}$in dichloromethane-toluene glass at $77 \mathrm{~K}$. Instrument settings: power, $30 \mathrm{~dB}$; modulation, $100 \mathrm{kHz}$; sweep centre, $3200 \mathrm{G}$.

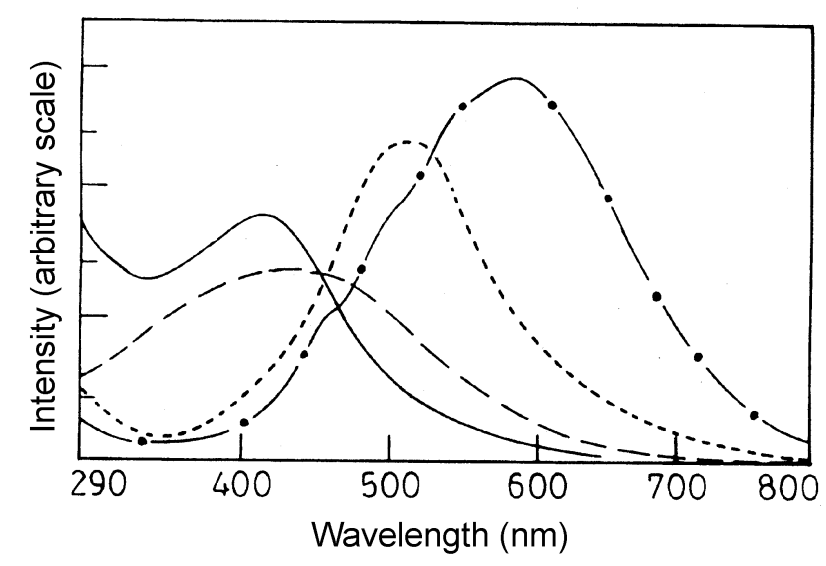

Figure 4. Absorption (-), excitation (- - -), and fluo-

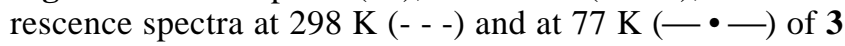
(Cl) in dichloromethane solution. 
sample (subscript $r$ ) and the standard reference (subscript std) respectively,

$$
\phi_{r}=\phi_{\mathrm{std}}\left(A_{\mathrm{std}} / A_{r}\right)\left(I_{r} / I_{\mathrm{std}}\right)\left(\eta_{r}^{2} / \eta_{\mathrm{std}}^{2}\right) .
$$

Excitation spectral studies show that fluorescence is associated with the absorption band near $400 \mathrm{~nm}$. A representative case is shown in figure 4. Assuming that the band has MLCT character as suggested above, the possible involvement of the ${ }^{3}$ MLCT state $^{13}$ incorporating $\pi^{*}(Q)$ contribution is implicated in the emission process. We also note that the parent organometallics of type $\mathbf{1}$ do not diplay any fluorescence in the visible region.

\section{Conclusions}

It is demonstrated that the metallacyclics of type $\mathbf{1}$ react smoothly with HQ furnishing aryl ruthenium organometallics of type $\mathbf{3}$. The conversion $\mathbf{1} \rightarrow \mathbf{3}$ is attended with cleavage of $\mathrm{Ru}-\mathrm{O}$ and $\mathrm{Ru}-\mathrm{Cl}$ bonds, $(\mathrm{N}, \mathrm{O})$ chelation of quinolin-8-olate, iminium-phenolato $\rightarrow$ imine-phenol tautomerization. $\mathrm{Ru}^{\mathrm{III}} / \mathrm{Ru}^{\mathrm{II}}$ reduction potentials are systematically lower than those of $\mathbf{1}$ and $\mathbf{3}$ is electrooxidizable to the ruthenium(III) analogue $\mathbf{3}^{+}$characterized by rhombic EPR spectra. The Ru $\rightarrow$ Q MLCT absorption in the visible region makes 3 fluorescent with quantum yields one order of magnitude less than that of the $\left[\mathrm{Ru}(\mathrm{bpy})_{3}\right]^{2+}$ standard.

\section{Acknowledgements}

I am greatful to Professor Animesh Chakravorty for encouragement and useful suggestions throughout the work. I also thank the Department of Science and Technology, and the Council of Scientific and Industrial Research, New Delhi for financial support.

\section{References}

1. Seddon K R 1981; 1982; 1985 Coord. Chem. Rev. 35 41; $4179 ; 67171$

2. Wong W T 1994 Coord. Chem. Rev. 13145

3. Ghosh B K and Chakravorty A 1989 Coord. Chem. Rev. 25239

4. Kalyansundaram K 1982 Coord. Chem. Rev. 46159

5. Cabeza J A, Rio I D, Granda S G, Riera V and Suarez M 2002 Organometallics 212540

6. Poyatos M, Mata J A, Falomir E, Crabtree R H and Peris E 2003 Organometallics 221110
7. Perez J, Riera V, Rodriguez A and Miguel D 2002 Organometallics 215437

8. Ghosh K, Pattanayak S and Chakravorty A 1998 Organometallics 171956

9. Ghosh K, Chattopadhyay S, Pattanayak S and Chakravorty A 2001 Organometallics 201419

10. Ferstl W, Sakodinskaya I K, Sutter N B, Borgne G L, Pfeffer M and Raybov A D 1997 Organometallics 16 411

11. Panda B K, Chattopadhyay S, Ghosh K and Chakravorty A 2002 Organometallics 212773

12. Ritleng V, Preffer M and Sirlin C 2003 Organometallics 22347

13. Yam V W W, Chu B W K, Ko C C and Cheung K K 2001 J. Chem. Soc., Dalton Trans. 1911

14. Yam V W W, Chu B W K and Cheung K K 1998 J. Chem. Soc., Chem. Commun. 2261

15. Ghosh P, Bag N and Chakravorty A 1996 Organometallics 153042

16. Bag N, Choudhury S B, Pramanik A, Lahiri G K and Chakravorty A 1990 Inorg. Chem. 295013

17. Bag N, Choudhury S B, Lahiri G K and Chakravorty A 1990 J. Chem. Soc., Chem. Commun. 1626

18. Chattopadhyay S, Ghosh K, Pattanayak S and Chakravorty A $2001 \mathrm{~J}$. Chem. Soc., Dalton Trans. 1259

19. Ghosh P, Pramanik A and Chakravorty A 1996 Organometallics 154147

20. Ghosh P and Chakravorty A 1997 Inorg. Chem. 36 64

21. Chattopadhyay S, Panda B K, Ghosh K and Chakravorty A 2001 Israel J. Chem. 41139

22. Panda B K, Chattopadhyay S, Ghosh K and Chakravorty A 2002 Polyhedron 21899

23. Panda B K, Ghosh K, Chattopadhyay S and Chakravorty A 2003 J. Organomet. Chem. 674107

24. Lahiri G K, Bhattacharya S, Ghosh B K and Chakravorty A 1987 Inorg. Chem. 264324

25. Bhattacharya S 1993 Polyhedron 12235

26. Pramanik N C and Bhattacharya S 1997 J. Chem. Res. 98

27. Menon M, Pramanik A, Bag N and Chakravorty A 1995 J. Chem. Soc., Dalton Trans. 1417, and references cited therein

28. Ghatak N, Chakravarty J and Bhattacharya S 1995 Polyhedron 143591

29. Stephenson T A and Wilkinson G 1966 J. Inorg. Nucl. Chem. 28945

30. Sawyer D T and Roberts J L Jr 1974 Experimental electrochemistry for chemists (New York: Wiley) p. 212

31. Sandorfy C and Vocelle D 1989 Mol. Phys. Chem. Biol. 4195

32. Ghosh P 1997 Polyhedron 161343

33. Hammett L P 1970 Physical organic chemistry 2nd edn (New York: McGraw-Hill)

34. Ghosh P, Pramanik A, Bag N, Lahiri G K and Chakravorty A 1993 J. Organomet. Chem. 454237

35. Rillema D P, Taghdiri D G, Jones D S, Worl L A, Meyaer T J, Levy H A and Keller C D 1987 Inorg. Chem. 26578 